Original Research

\title{
Autonomous Hydrogen Production for Proton Exchange Membrane Fuel Cells PEMFC
}

Manuel Legree ${ }^{1}$, Jocelyn Sabatier ${ }^{2}$, Fabrice Mauvy ${ }^{1}$, Abdel salam Awad ${ }^{1,3}$, Matthieu Faessel ${ }^{4}$, Frédéric Bos ${ }^{4}$, Jean-Louis Bobet ${ }^{1, *}$

1. Bordeaux University - CNRS, ICMCB Lab, UMR 5026, 87 Avenue du Dr Schweitzer, 33608 Pessac, France; E-Mails: manuel.legree@icmcb.cnrs.fr; fabrice.mauvy@icmcb.cnrs.fr; camnizaro@hotmail.com; jean-louis.bobet@u-bordeaux.fr

2. Bordeaux University, IMS Lab, UMR 5218, 351 Cours de la Libération, 33405 Talence, France; E-Mail: jocelyn.sabatier@u-bordeaux.fr

3. LCPM, Lebanon University, Faculté des Sciences 2, 90656 Jdeidet El Matn, Lebanon

4. Bordeaux University, TechnoShop Coh@bit platform, Bordeaux Institute of Technology, 15 Rue Naudet, 33750 Gradignan, France; E-Mails: matthieu.faessel@u-bordeaux.fr; frederic.bos@u-bordeaux.fr

* Correspondence: Jean-Louis Bobet; E-Mail: jean-louis.bobet@u-bordeaux.fr

Academic Editor: Alfonso Chinnici

Special Issue: $\underline{\text { Hydrogen Energy: Sustainable Production, Storage and Utilisation }}$

Journal of Energy and Power Technology Received: March 04, 2020

2020, volume 2 , issue 2

Accepted: April 17, 2020

doi:10.21926/jept.2002004

Published: April 28, 2020

\begin{abstract}
This paper focuses on hydrogen production for green mobility applications (other applications are currently under investigation). Firstly, a brief state of the art of hydrogen generation by hydrolysis with magnesium is shown. The hydrolysis performance of Magnesium powder ball-milled along with different additives (graphite and transition metals $\mathrm{TM}=\mathrm{Ni}, \mathrm{Fe}$, and $\mathrm{Al}$ ) is taken for comparison. The best performance was observed with $\mathrm{Mg}-10 \mathrm{wt} . \% \mathrm{~g}$ mixtures (95\% of theoretical hydrogen generation yield in about $3 \mathrm{~min}$ ). An efficient solution to control this hydrolysis reaction is proposed to produce hydrogen on demand and to feed a PEM fuel cell. Tests on a bench fitted with a $100 \mathrm{~W}$ Proton Exchange
\end{abstract}

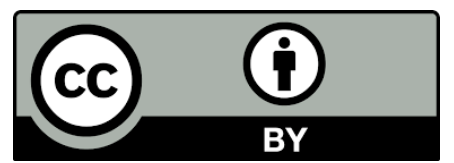

(C) 2020 by the author. This is an open access article distributed under the conditions of the Creative Commons by Attribution License, which permits unrestricted use, distribution, and reproduction in any medium or format, provided the original work is correctly cited. 
Membrane (PEM) fuel cell have demonstrated the technological potential of this solution for electric assistance applications in the field of light mobility.

\section{Keywords}

Hydrogen generation; Mg-based materials; hydrolysis reaction; command law; PEMFC; green mobility applications

\section{Introduction}

Many experts see the future of mobility on hydrogen use $\left(\mathrm{H}_{2}\right)$. Due to its modularity (it can be used in combustion engines or via a fuel cell), high conversion energy (three times that of hydrocarbons), and harmless nature (none to very low emission of $\mathrm{CO}_{2}$ and particulate matter), hydrogen is a promising candidate for chemical energy storage. However, the development of hydrogen use in the public domain currently raises the question of its production and storage. In many countries, the required infrastructure for production, transport, storage, and distribution does not exist and would be difficult to achieve. Large scale development of hydrogen for application in mobility is thus slowed down due to low availability. Moreover, accessible hydrogen is mainly produced by hydrocarbon reforming, which leads to significant emission of $\mathrm{CO}_{2}$. The work presented in this paper is thus a contribution to improving the accessibility of hydrogen for production, storage, and use. The photocatalysis or equivalent methods are intensively studied and shows interesting results [1, 2]. Also, many studies have been performed on sodium borohydride, $\mathrm{NaBH}_{4}$, or lithium borohydride, $\mathrm{LiBH}_{4}$, to examine its potential to store and release $\mathrm{H}_{2}$ gas [3-10]. This paper proposes a different approach to produce, store, and release $\mathrm{H}_{2}$ gas simultaneously, through production on demand. The proposed solution is new, cost-efficient, and safe. The "on-demand hydrogen production" concept is based on water hydrolysis using a mixture of magnesium powder and electronically controlled within a specially designed reactor. Many studies focused on magnesium alloys or aluminum alloys for water hydrolysis, [11-14] given the abundance of the reagents, and the large amount of energy produced by the chemical reaction. In this study, magnesium was preferable over aluminum because of its lower cost. Thus, the "ondemand hydrogen production" concept developed in this paper seems to be a highly attractive solution to increase autonomy not only for green mobility but also for a range of power systems. Among fuel cell technologies, PEM is of particular interest because it works at low temperatures with a quick start-up time and offers good power to weight ratio. These characteristics make PEM fuel cell suitable for light mobility application, and thus coupled with the system presented here. Such advantages also encourage studies aimed to improve PEM performance $[15,16]$. It involves, for instance, increasing the operating temperature (diminishes the sensitivity of electrodes to impurities (carbon monoxide), reduces toxicity, and enhances reaction kinetics), improving the proton conductivity of the electrolyte for better efficiency, or even designing smart electrodes to get rid of expensive catalyst (Platinum) [17-19].

Some of the chemical aspects of water hydrolysis with magnesium show the potential of transition metals ( $\mathrm{TM}=\mathrm{Ni}, \mathrm{Fe}$, and $\mathrm{Al}$ ) and oxide additives to improve hydrolysis performance. The solution proposed by the authors using carbon (graphite and carbon fibers) as additives is 
presented here. This mixture is used to "produce hydrogen on-demand" in a specially designed reactor. The reactor is extensively controlled to fill a PEM fuel cell. The efficiency of the control to maintain a constant hydrogen pressure inside a buffer tank located upstream of the fuel cell demonstrates its promising performance in an electrically assisted bike.

\section{Hydrogen Production Using Magnesium: State of the Art and a New Solution}

This section recalls some results concerning the hydrolysis of water using magnesium and proposes new results in hydrogen production.

\subsection{A Review of Pure Magnesium for Hydrolysis}

Magnesium is the $7^{\text {th }}$ most abundant element on earth, mainly in the form of carbonates or chlorides. Due to this abundance, it is preferable for hydrogen production. It also has other highly relevant properties. It is cost-effective (around $2.1 € / \mathrm{kg}$ ), and has a high mass capacity for hydrogen storage (7.6 wt.\%) in the form of magnesium hydride $\left(\mathrm{MgH}_{2}\right)$. Magnesium hydride has the highest energy density $(9 \mathrm{MJ} / \mathrm{kg} \mathrm{Mg}$ ) among all hydrides. It also has one of the weakest volume capacities of all hydrides $\left(108 \mathrm{~kg} / \mathrm{m}^{3}\right)$, greater than that of liquid hydrogen $\left(71 \mathrm{~kg} / \mathrm{m}^{3}\right)$ [20-22].

The reaction of magnesium $(\mathrm{Mg})$ with water produces pure hydrogen according to the following chemical equation:

$$
\mathrm{Mg}+2 \mathrm{H}_{2} \mathrm{O}=\mathrm{Mg}(\mathrm{OH})_{2}+\mathrm{H}_{2} \quad \Delta_{\mathrm{r}} \mathrm{H}^{\circ}=-354 \mathrm{~kJ} \cdot \mathrm{mol}^{-1}
$$

The thermodynamic diagram E versus $\mathrm{pH}$, also known as Pourbaix diagrams (see Figure 1) [1921], is used to explain the water hydrolysis reaction with magnesium metal, viewed as a corrosion process. The standard potential for the $\mathrm{Mg}^{2+} / \mathrm{Mg}$ redox couple $\mathrm{E}^{\circ}\left(\mathrm{Mg}^{2+} / \mathrm{Mg}\right)$ is $-2.37 \mathrm{~V} / \mathrm{ESH}$ (corresponding to standard free energy $\left.\Delta_{\mathrm{r}} \mathrm{G}^{\circ}=-457 \mathrm{~kJ} \cdot \mathrm{mol}^{-1}\right)$. It is well below $\mathrm{E}^{\circ}\left(\mathrm{H}_{2} / \mathrm{H}_{2} \mathrm{O}\right)$ that is close to $-0.42 \mathrm{~V} / \mathrm{ESH}$ (at $\mathrm{pH}=7$ ). From these comments, it is evident that the global reaction (1) depicts a "local" electrochemical cell that undergoes the following redox and acid-base reactions:

$$
\begin{aligned}
& \text { Magnesium oxidation: } \mathrm{Mg}=\mathrm{Mg}^{2+}+2 \mathrm{e}^{-} \\
& \text {Water auto-protolysis: } 2 \mathrm{H}_{2} \mathrm{O}=2 \mathrm{OH}^{-}+2 \mathrm{H}^{+} \\
& \text {Magnesium hydroxide formation: } \mathrm{Mg}^{2+}+2 \mathrm{OH}^{-}=\mathrm{Mg}(\mathrm{OH})_{2} \\
& \text { Water reduction (di-hydrogen production): } 2 \mathrm{H}^{+}+2 \mathrm{e}^{-}=\mathrm{H}_{2}
\end{aligned}
$$

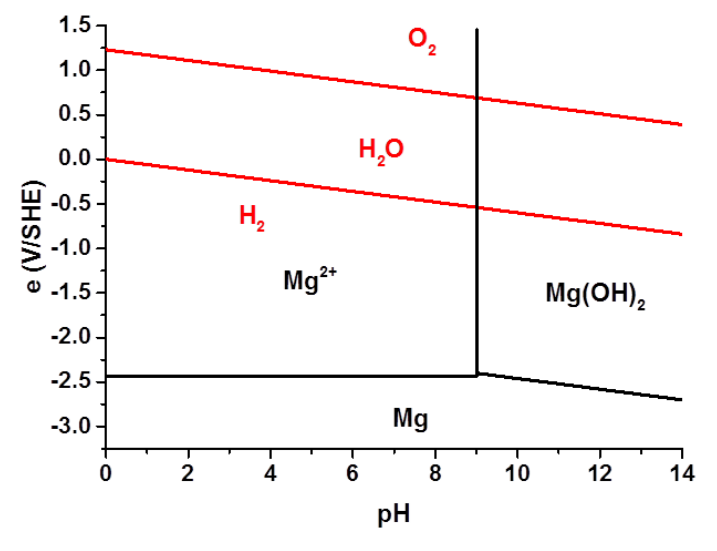

Figure $1 \mathrm{E}$ vs. pH for magnesium species and water [23]. 
The hydrolysis reaction of $\mathrm{MgH}_{2}$ has the mass yield of hydrogen close to $6.4 \%$ if the mass of water in the reaction is under consideration, and $15.2 \%$ if not. Moreover, this reaction produces solid magnesium hydroxide $\mathrm{Mg}(\mathrm{OH})_{2}$. This is an advantage as $\mathrm{Mg}(\mathrm{OH})_{2}$ is harmless. These yields fall with metallic $\mathrm{Mg}$. They reach 3.3\%, taking into account water in the computation, or $8.2 \%$ without taking water into account. The electrolyte reaction is indeed quickly interrupted by a passive layer of magnesium hydroxide formed at the surface of magnesium or its hydride.

Figure 2 shows an increase in the scientific studies published between 1897 and 2018 on the production of hydrogen upon hydrolysis with magnesium and its hydride. It demonstrates that hydrogen production using hydrolysis with magnesium has experienced a renewal of interest in recent years, although this reaction was well known for a long time. Most of the published works deal with solutions to overcome the passivation problem, as previously mentioned. The solutions cited are as follows:

(i) increasing the water temperature to enhance the hydrolysis rate of $\mathrm{Mg}-\mathrm{H}$;

(ii) using additives during hydrolysis as ion exchangers or buffering agents to delay the formation of the passive layer $\left(\mathrm{Mg}(\mathrm{OH})_{2}\right)$;

(iii) using doping additives and mechanical grinding for exfoliation of the hydroxide layer, thus creating numerous surface defects.

In this study, the last two classes of solutions were investigated.

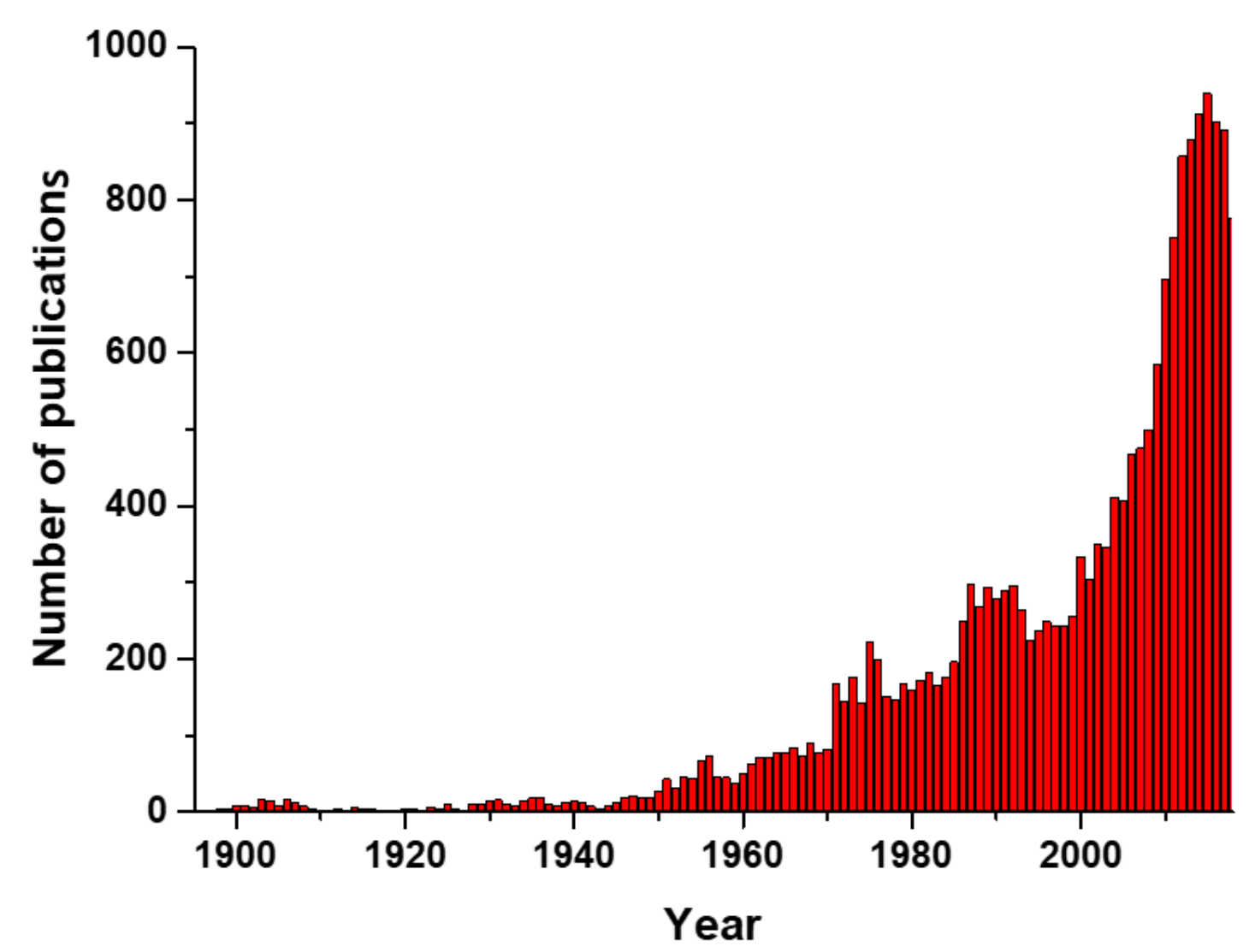

Figure 2 Number of scientific articles dedicated to the hydrolysis reaction of magnesium in the period 1897-2018. Source: SciFinder, a CAS Solution. [database]. American Chemical Society 2019. 


\subsection{Analysis of the Effects of Chemical and Mechanical Parameters}

Material grinding decreases the particle size, and thus increases the contact surface between the resulting powder and water [24], thereby improving the reaction efficiency: after $30 \mathrm{~min}$, the hydrolysis reaction yield for $\mathrm{MgH}_{2}$ increases from $8 \%$ for the un-milled hydride to $33 \%$ with a powder obtained after 3-hour grinding. However, with a 5 -hour grinding, the reaction yield drops to $24 \%$ [25]. Two phenomena explain this decrease as the grinding time increases:

(i) welding of the grains, leading to a reduction in the reaction surface;

(ii) powder surface oxidation of the powder $[25,26]$.

It must be noted that the crushing of pure magnesium has no impact on the hydrolysis kinetics in pure water, as the specific surface remains almost the same. This is different for the hydride, as it is more fragile [26, 27]. Another advantage of grinding is the creation of surface defects that are assumed to have a positive impact on the exfoliation of the hydroxide layer.

\subsection{Effect of Additives}

Specific additives improved magnesium hydrolysis reaction performance. In has been shown in the literature $[27,28]$ that the reaction of an $\mathrm{MgH}_{2} / \mathrm{Ca}$ mixture (with 20at.\% Ca) undergoes a $75 \%$ conversion after $30 \mathrm{~min}$. In comparison with $\mathrm{MgH}_{2}$ milled alone, this highlights a real increase in the volume of $\mathrm{H}_{2}$ produced. When salts are added during grinding $\left(\mathrm{LiCl}, \mathrm{NaCl}, \mathrm{MgCl}_{2}, \mathrm{KCl}, \mathrm{NiCl}_{2}\right.$, $\left.\mathrm{AlCl}_{3}, \mathrm{FeCl}_{3}\right)[28,29]$, the efficiency and the kinetics of the reaction can be significantly improved. Cold welding phenomena can indeed be prevented, thanks to the chlorides that produce more defects, and a "clean" and fresh surface. For illustration, a hydrolysis yield of $98 \%$ can be obtained after 2 min using an $\mathrm{Mg}-10 \% \mathrm{FeCl}_{3}$ mixture [30]. The authors [31] explained that the metal reduced to $\mathrm{M}^{0}$ during the grinding process as a result of the replacement reaction between $\mathrm{Mg}$ and the chlorides. During hydrolysis, an electrochemical interaction (a local galvanic cell) [32-36] occurs between metallic elements in the presence of $\mathrm{Mg}$ in the alkaline medium, which plays a crucial role in the reaction efficiency improvement.

In such a context, it has been shown that mixtures with transition metals could be accelerated to achieve the hydrolysis reaction. In an earlier study [26], it was shown that $\mathrm{Mg}-10 \%$, along with $\mathrm{Ni}$ composite, milled for 30 min produces the total theoretical hydrogen within $1 \mathrm{~h}$, in a salt solution. This is due to the presence of chloride ions, leading to the creation of a micro-galvanic cell between dispersed $\mathrm{Ni}$ elements and $\mathrm{Mg}$. A conducting solvent is required to create these micro-galvanic cells, which explains the fact that no effects showed up with transition metals in pure water. It is also necessary for the aided reagent to be a good conductor of electrons. Due to its band gap of $5 \mathrm{eV}$, this is not the case for magnesium hydride, as the corrosion and galvanization processes are quickly interrupted.

\subsection{Proposed Mixture}

In this work, another additive was tested following the results cited in the previous sections, in terms of preparation and solution for the reaction. The mixture consisted of a ball-milled $\mathrm{Mg}$ powder with carbon additive, and the hydrolysis reaction accomplished with an aqueous solution containing $\mathrm{NaCl}$. Figure 3 gives the hydrolysis reaction conversion ratio as a function of time to compare the reactions conducted using different additives, as mentioned in the previous section. 
It shows that $\mathrm{Mg}-10 \mathrm{wt} . \%$ carbon in aqueous solution, along with $3.5 \mathrm{wt} . \%$ of $\mathrm{NaCl}$, gives a better hydrolysis reaction performance than those previously proposed in the literature [25]. For Mg-10 wt.\% C (Graphite (G) or Carbon fibers (CFs)), the hydrogen generation reaches $45 \%$ of the theoretical value after $30 \mathrm{~s}$. The highest fraction of hydrogen is produced in the first few minutes, with a conversion ratio close to $80 \%$ after $4 \mathrm{~min}$ (and even a full conversion after 6 to $7 \mathrm{~min}$ ). In comparison, a mixture with $\mathrm{Fe}$ and $\mathrm{Ni}$ needs $30 \mathrm{~min}$ to release 81 and $97 \%$ of the theoretical hydrogen yield, respectively. From Figure 3, it is clear that $\mathrm{Mg}-10 \mathrm{wt} . \% \mathrm{Ni}$ shows better hydrolysis performance. It suggests that the nature of the transition metals, and not just the morphological aspect of the grains, affect the overall hydrogen yield and reaction rate.

Beyond yield and reaction rate considerations, the proposed solution has the advantage of not generating impurities, as residues consist only of innocuous materials. In fact, the solution also retains the advantages of hydrogen production by water hydrolysis with magnesium, as it is free of $\mathrm{CO}_{2}$ and particulate emission.

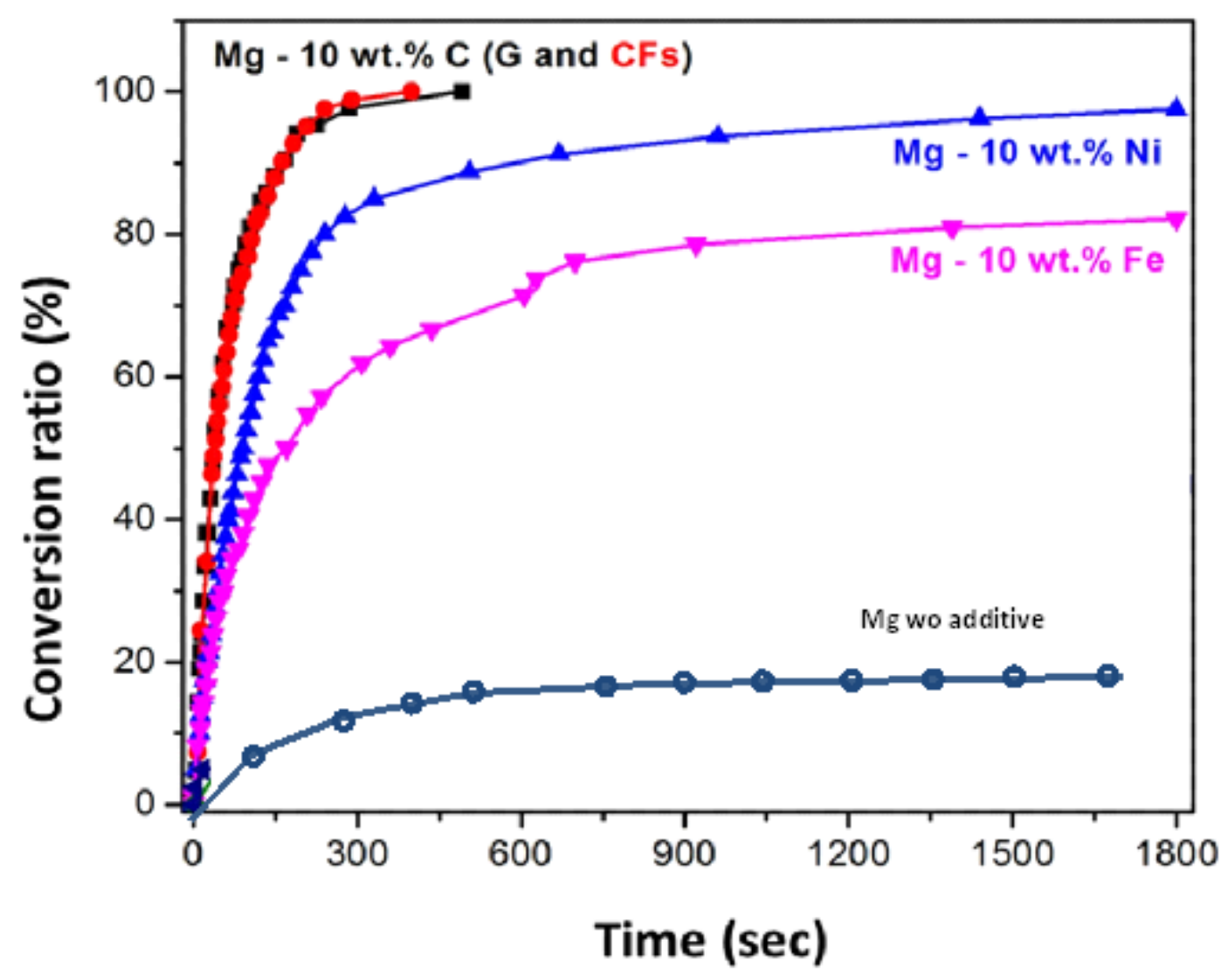

Figure 3 Evolution of the hydrogen conversion ratio versus time, with powders $\mathrm{Mg}$ without additive and $\mathrm{Mg}-10 \mathrm{wt} . \% \mathrm{X}(\mathrm{X}=\mathrm{G}, \mathrm{CFs}$ (Carbon Fibers), Ni, Fe) in an aqueous solution containing $3.5 \mathrm{wt} . \% \mathrm{NaCl}$.

The efficiency of the proposed powdered mixture can be explained using Figure 4. The hydrolysis rate and reaction yield increase significantly in the presence of a salt. This is shown in an earlier study [26]. Due to the chloride ions in the reaction medium (a saline solution), the hydrolysis reaction of the mixture $\mathrm{Mg} / \mathrm{Ni} 10 \mathrm{wt} . \%$ is almost complete. The conversion efficiency from $\mathrm{Mg}$ to $\mathrm{Mg}(\mathrm{OH})_{2}$ (and $\mathrm{H}_{2}$ ) increases in a chloride solution. This is due to the destabilization of magnesium hydroxide $\left(\mathrm{Mg}(\mathrm{OH})_{2}\right)$ passivation layer by chloride ions, $\mathrm{Cl}^{-}$[24, 25]. Indeed, 
magnesium chloride $\mathrm{MgCl}_{2}$ is formed by the substitution of $\mathrm{Cl}^{-}$ions instead of $\mathrm{OH}^{-} . \mathrm{MgCl}_{2}$ salt is more soluble in water than $\mathrm{Mg}(\mathrm{OH})_{2}$. As a result, at the grain surface, there is local destruction of the passivation layer, as illustrated in Figure 4. Also, the hydrolysis reaction performance of the magnesium hydride, $\mathrm{MgH}_{2}$, is enhanced by reducing the $\mathrm{pH}$ of the reaction medium, for instance, by increasing the acid concentration $[25,26]$. In an acidic medium ( $\mathrm{pH}$ close to 1 ), complete conversion occurs within $100 \mathrm{~s}$. The hydrolysis reaction thus possesses high kinetics. Due to the kinetic factor and the substitution reaction previously described, the solution containing the hydroxide ions are neutralized by the protons in the acid medium.

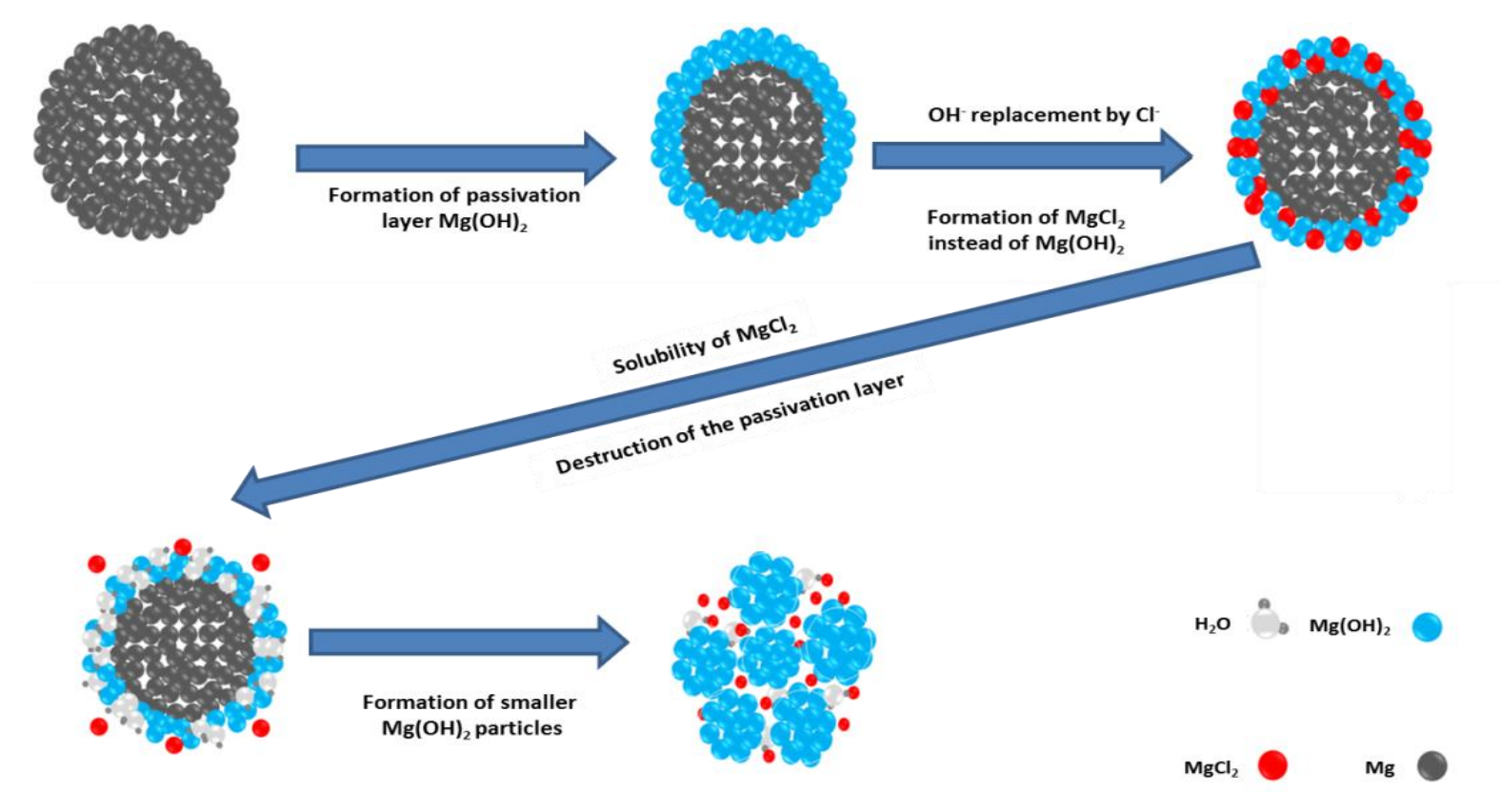

Figure 4 Schematic analysis of the impact of chloride ions on the Hydrolysis reaction.

\subsection{Investigation of Magnesium Alloy Wastes for Hydrogen Production}

Currently, the recycling of alloy wastes to secondary ingot concerns only high purity magnesium (Classes 1 and 2). More than half of the Mg wastes (Classes 3 to 8, i.e., low-grade alloys) are not recycled as it is not economically viable [36-38]. However, it was shown recently [39-41] that these alloys (Classes 1 to 8 ) produce hydrogen through hydrolysis using a 3.5 mass\% aqueous solution of $\mathrm{NaCl}$. The reaction is catalyzed using a platinum-coated titanium net (namely, Ti-Pt) [39-41] and 304 stainless steel [36]. The energy required to recycle the $\mathrm{Mg}$ alloy into the secondary ingot (see Figure 5) is between 7.2 to $14.2 \mathrm{MJ} / \mathrm{kg}$. This is greater than the energy required to produce hydrogen from $\mathrm{Mg}$ waste evaluated to be $3.9 \mathrm{MJ} / \mathrm{kg}$ [36], for instance, for the insertion of the catalyst. As a consequence, using $\mathrm{Mg}$ waste to produce hydrogen is thus economically viable. The conversion efficiency and kinetics of the hydrolysis reaction can be improved using citric acid [42, 43]. Consequently, citric acid added to fresh seawater can be used to achieve the total reactivity of the magnesium. As the yield and rate of $\mathrm{H}_{2}$ production are significantly increased with citric acid, no catalyst is required [44-47].

Besides, the authors are presently working on $\mathrm{Mg}$ waste recycling for hydrogen production, in an attempt to adapt the formulation proposed in Section 2.4 to achieve large yields and rate reactions. 

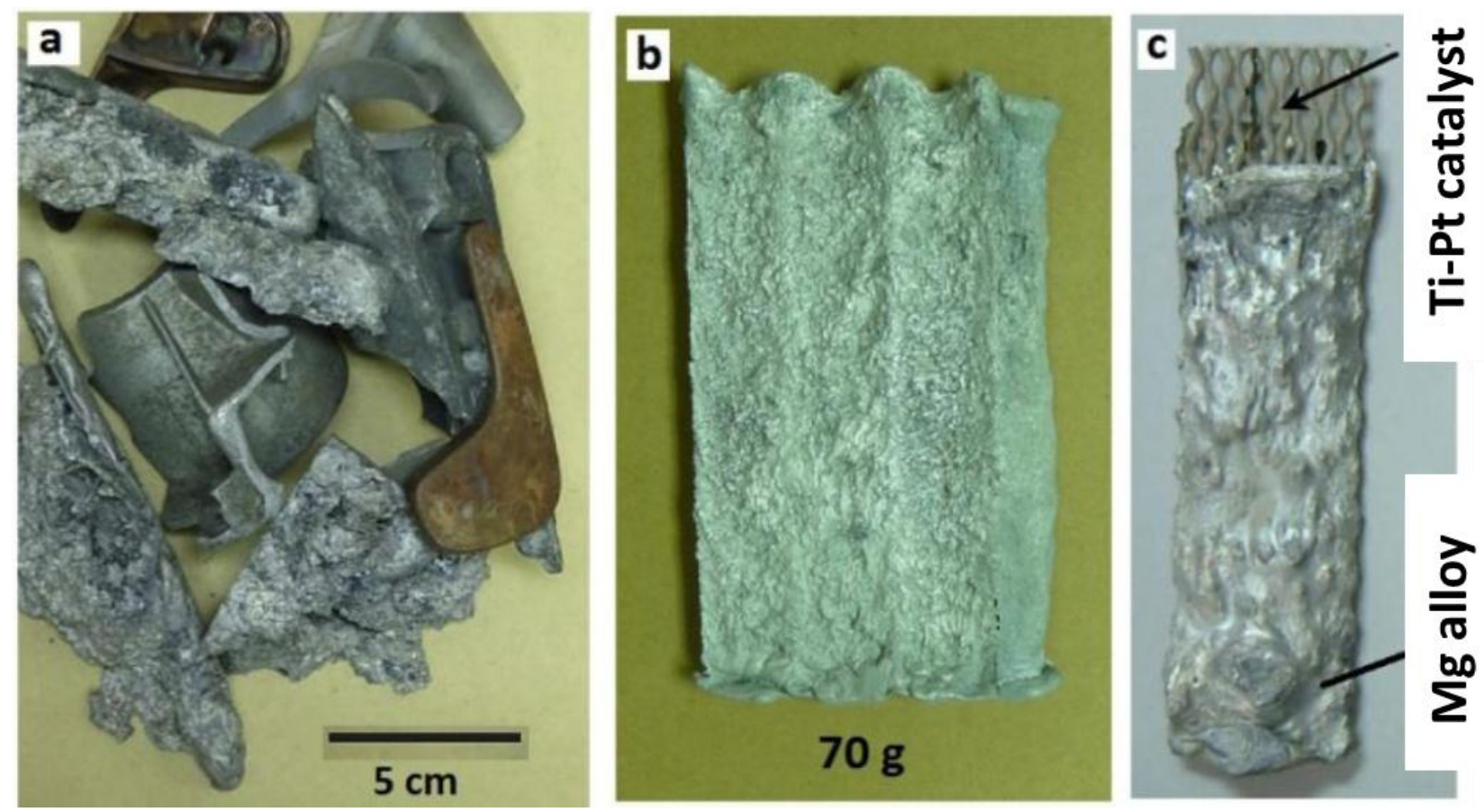

Figure 5 Pictures of (a) Mg alloy wastes, (b) Mg alloys recycled for hydrogen production, (c) recycled alloy with Ti-Pt catalyst [33].

\section{Generator for Hydrogen Reaction}

\subsection{Description of the Hydrogen Production System}

Relation (1) delineates a spontaneous and complete reaction (if the preparation is done according to the description in Section $2.4[48,49])$. It stops only upon complete consumption of one of the two reagents (magnesium or water). In order to avoid using a storage tank in electrical applications when fed with a PEM fuel cell, the best solution is to produce hydrogen on demand, while the PEM fuel cell produces electricity [50]. An instrumental reactor was thus designed to control the reaction kinetics. A sectional view of this reactor is shown in Figure 6 . The water tank contains an immersed peristaltic pump (2). Such a pump permits water flow proportional to the control voltage applied to the motor driver and makes easier the synthesis of kinetic control law design. The magnesium-based powder is inside the removal capsule (3), and the water is contained in the compartmental tank. Reaction (1) highlights that a stoichiometry ratio of 1.5 is needed between the mass of magnesium powder and that of water. Magnesium powder is sprayed with water that flows through the nozzle (5). Hydrogen is then produced and flows into the water tank via a non-return valve (6). The produced hydrogen cools and is temporarily stored in the tank (1) (that acts as a buffer volume), thus leading to the partial condensation of the water vapor contained in the hydrogen. Heat-pipe cooling system (4) mounted on the reactor permits the thermal management of the exothermic reaction (1). Such a system limits the temperature rise during the test to a maximum of $5{ }^{\circ} \mathrm{C}$. The temperature of the reaction chamber is monitored and measured using a PT1000 probe. The reactor is fitted with sensors that measure the tank (1) and the reaction chamber pressures. Two safety valves ensure the security of the reactor. 


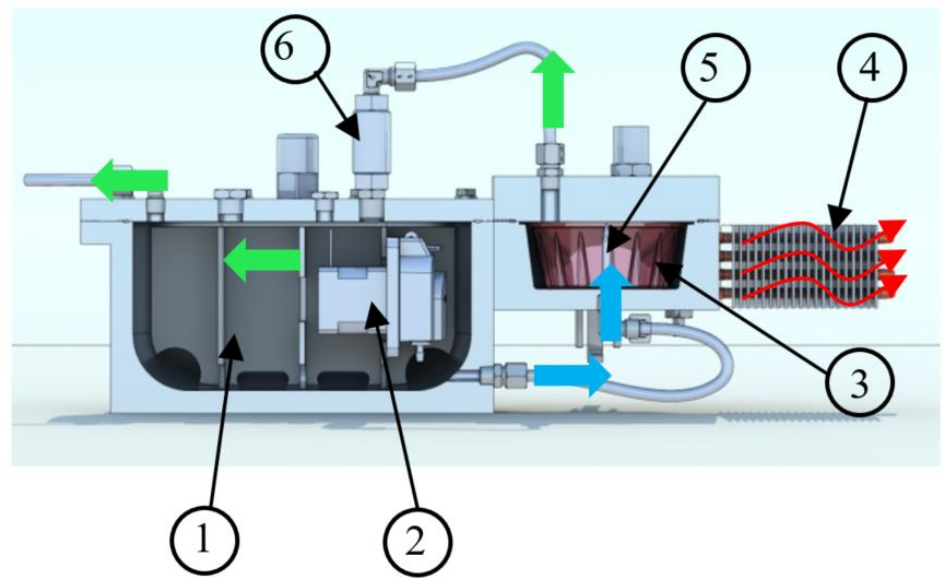

\section{Water circulation}

Hydrogen circulation

Heat exchange

Figure 6 Sectional view of the reactor designed for hydrogen production on demand.

\subsection{Non-Supervised Testing}

As a preliminary test, an open-loop control voltage was applied to the peristaltic pump (2) of the $\mathrm{H}_{2}$ production system described in the previous sub-section. The test was done with a capsule holding $10 \mathrm{~g}$ of magnesium powder. Figure 7 shows the voltage control signal applied to the pump, along with the resulting hydrogen pressure inside the reactor. This figure shows that the amount of hydrogen produced by the reactor is directly proportional to the amount of injected water. Upon stopping the pump and total consumption by the reaction, the hydrogen pressure inside the tank remains constant, and the hydrolysis reaction stops. Upon successive injection of water, the reaction restarts, and the pressure increases.
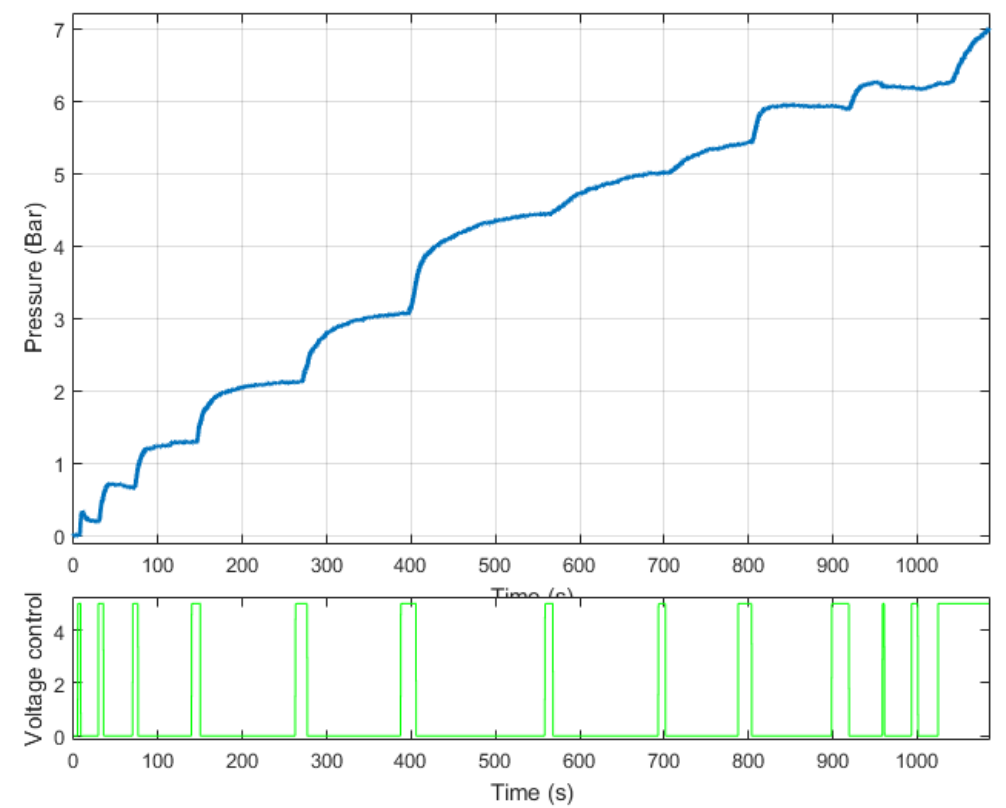

Figure 7 Voltage control signal applied to the pump (bottom green) and resulting pressure variation (top blue). 
As:

- the flow of injected water is proportional to the pump driver control voltage,

- the reaction stoichiometry is imposed by reaction (1),

it is possible (i) to compute the amount of magnesium left unconsumed inside the capsule, and then (ii) to create a complete reaction gauge.

\section{Controlled Hydrogen Production}

\subsection{Description of the Test Bench}

The reactor described in Section 3 is included in the test bench, as shown in Figure 8. This bench is fitted with a 100W PEM type fuel cell. To be operational in a fuel cell, the pressure in the hydrogen produced is regulated to 1.6 bars. A resistor that acts as a load is connected to the fuel cell via an electronic switch controlled in PWM mode by the bench supervisor. A flow meter is connected to the output of the reactor to measure the flow of the hydrogen produced. The pressure and temperature inside the reactor are measured by the bench supervisor, along with the values of current and voltage at the load terminals. The supervisor also controls several safety devices and informs the operator when the reaction of magnesium inside the reactor is complete. Another role of the bench supervisor is to control the hydrolysis reaction kinetics to regulate the time evolution of hydrogen pressure inside the reactor $P(t)$. This control is carried out by the regulation of water that flows through the reactor by varying the pump driver voltage $V(t)$. The control loop that maintains the pressure at the reference value $P_{\text {ref }}(t)$ is represented in Figure 9 .

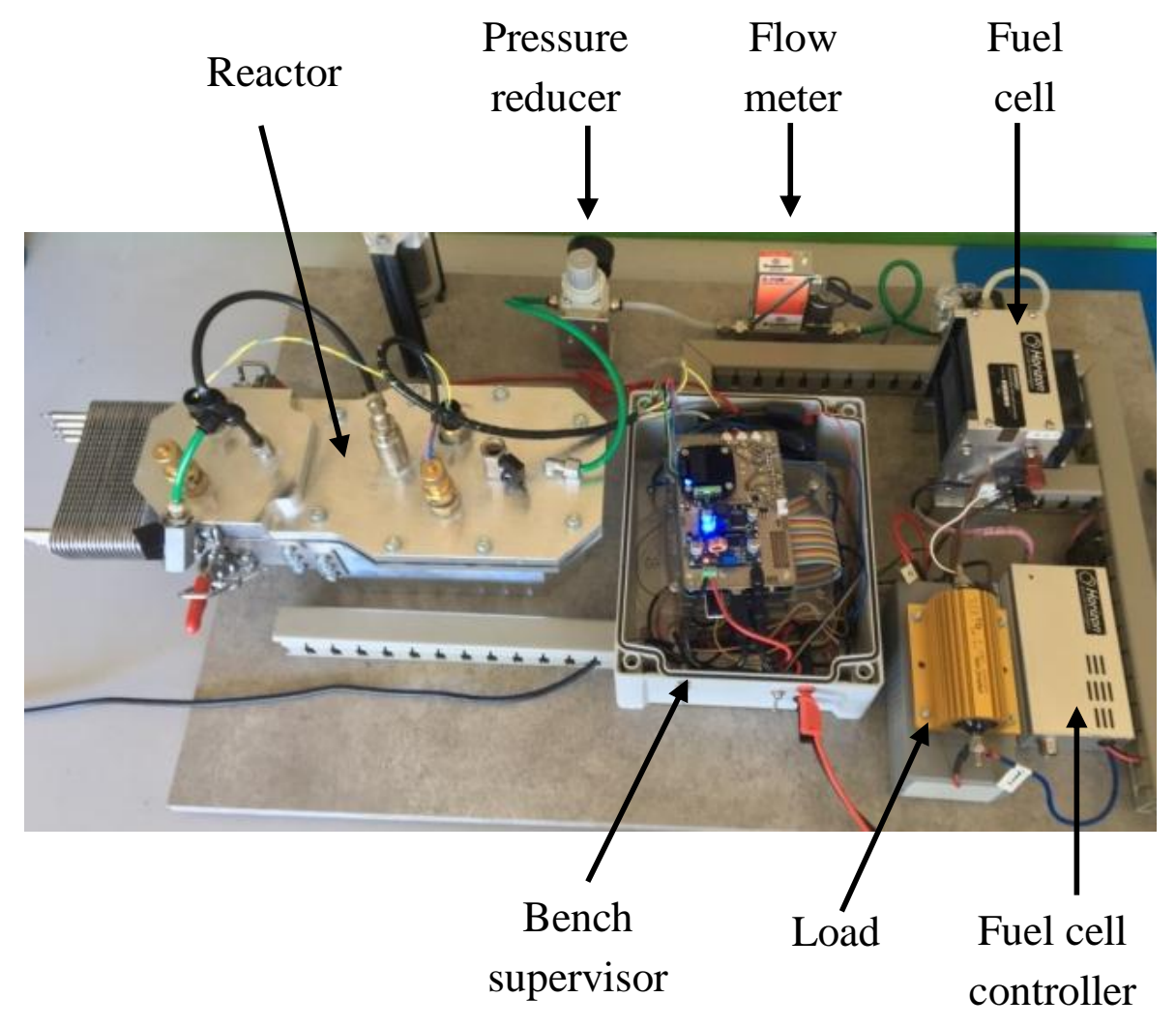

Figure 8 Test bench designed on which a 100W PEMFC fuel cell (right) and the hydrogen reactor (left) are mounted. 


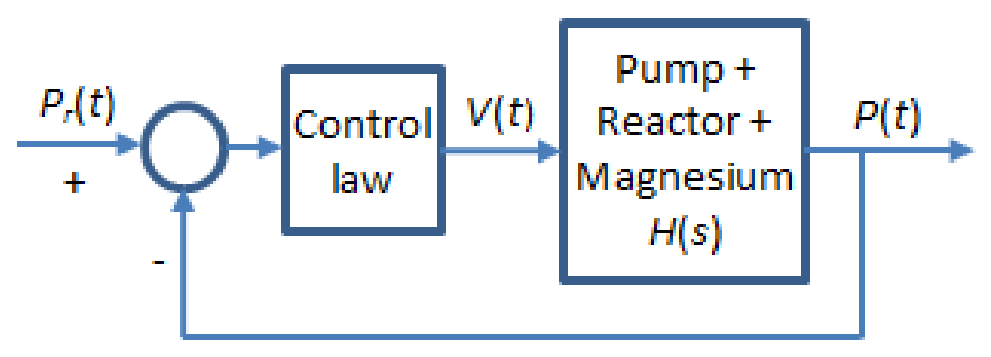

Figure 9 Pressure control loop associated to the reactor.

\subsection{Analysis of the Dynamic Behavior of the Pressure Control Loop}

The design of a controller requires the dynamic behavior characterization of the system to be controlled. For the reactor pressure regulation by the control of water flow, the dynamic system that links the pump driver voltage $V(t)$ to the reactor pressure $P(t)$ must be calculated. To achieve this goal, limited-duration step input voltages are applied to the pump driver to excite the system. Figure 7 shows the resulting pressure variations and reveals a slightly non-linear system. Whatever the operating temperature and pressure, the pressure variations are comparable, despite the different step durations. The system can thus be represented as a linear model, whose transfer function is denoted by $H(s)$, where $s$ is the Laplace variable. From Figure 10 that portrays several parts of the curves in Figure 7, it is concluded that the pressure evolves with a transport delay compared to the variation in the pump voltage (part 1). The pressure response exhibits a quasilinear rise (in part 2) and shows a long memory relaxation on stopping the pump (part 3).

According to this analysis, it is proposed to use the transfer function $H(s)$ defined by:

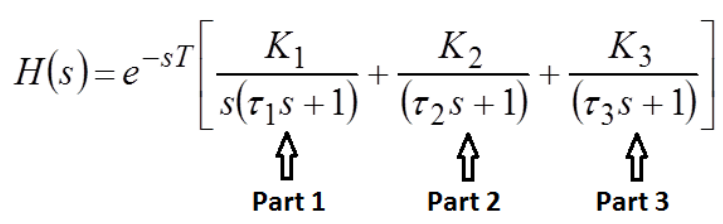

as a dynamic model of the system. In relation (6), $T(\mathrm{sec})$ denotes the model time delay, $K_{\mathrm{i}}($ bars $/ \mathrm{V}$ ), where $i$ is an integer with values 1,2 , or 3 that are model gains, and ${ }_{i}(\mathrm{sec})$ represents model time constants.

From the time responses in Figure 10, numerical values of the parameters $T, K_{\mathrm{i}}$, and ${ }_{i}(\mathrm{sec})$ are evaluated for various operating pressures using a non-linear optimization algorithm. Criterion associated with this problem aims at minimizing the time response differences between the model output and the recorded data, inputs being the limited duration steps in Figure 10 . Such an optimization problem solved at various operating pressures permits the following inequalities:

$$
\begin{aligned}
& 3.8929 \times 10^{-3} \leq K_{1} \leq 1.9609 \times 10^{-2} \\
& 1.1188 \times 10^{-1} \leq K_{2} \leq 1.0061 \times 10^{2} \\
& 1.1142 \times 10^{1} \leq K_{3} \leq 1.4938 \times 10^{2} \\
& 4.4598 \leq \tau_{1} \leq 7.4150 \times 10^{1} \\
& 1.7927 \times 10^{1} \leq \tau_{2} \leq 2.2138 \times 10^{4} \\
& 1.7927 \times 10^{1} \leq \tau_{3} \leq 7.3709 \times 10^{4} \\
& 1 s \leq T \leq 9 s
\end{aligned}
$$


Figure 10 shows the comparison between the system and the model pressure responses. This figure demonstrates that the dynamic behavior of the system is well fitted using the model described by relation (6), and the associated parameter values (relations (7) to (13)).

Upon dynamic characterization, a switch-like controller was designed and applied in the control loop, as in Figure 9.
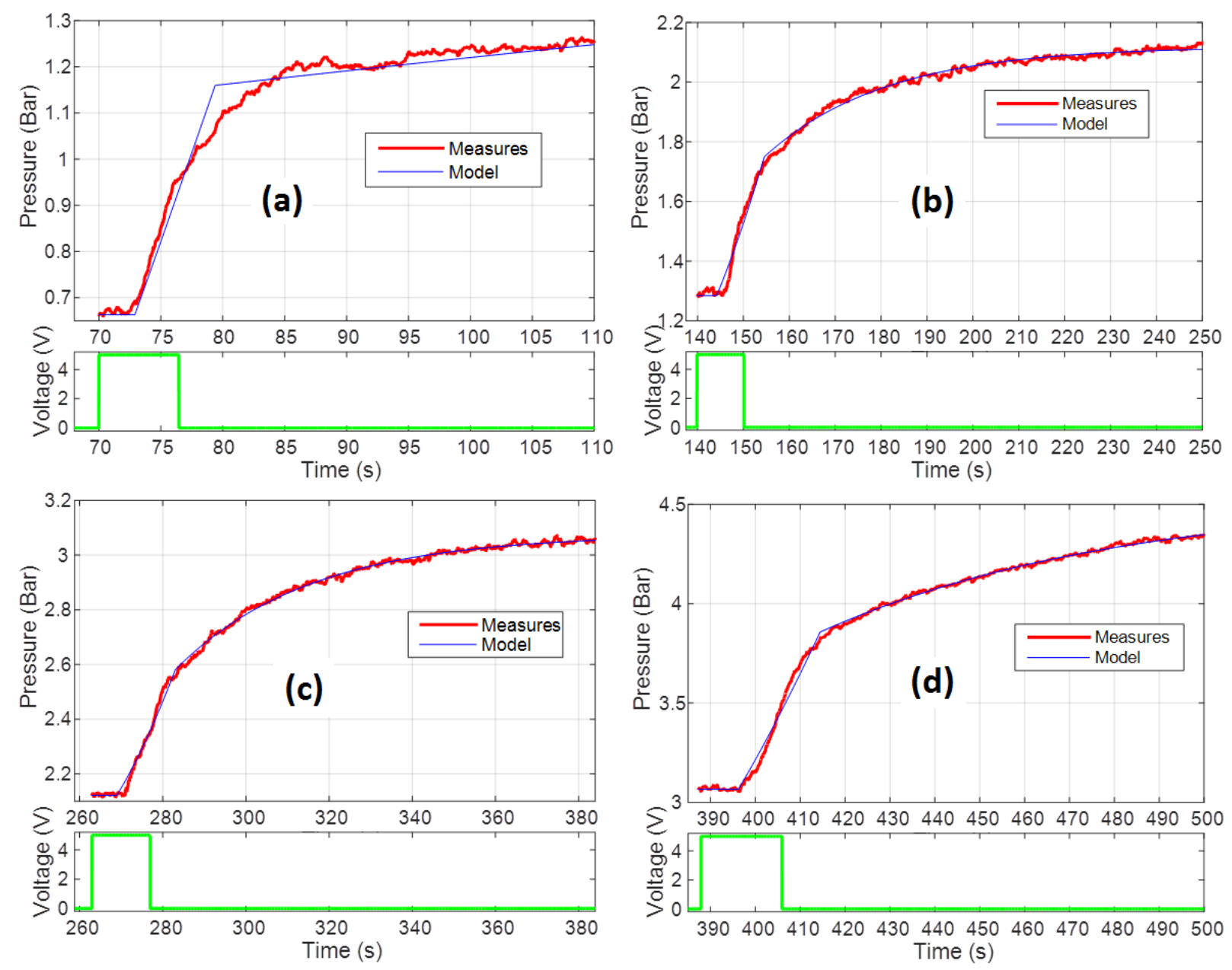

Figure 10 Comparisons of the reactor internal pressure variations with the model responses for various operating conditions: (a) from 0.7 bar to 1.2 bar, (b) from 1.3 bar to 2.1 bar, (c) from 2.1 bar to 3 bar, (d) from 3 bar to 4.5 bar.

\subsection{System Behavior in Real Operation}

The behavior of the pressure regulation loop is analyzed in this sub-section. A test was conducted using $15 \mathrm{~g}$ of magnesium powder, and the pressure reference was taken to be 2.5 bars. Pressure variations within the reactor versus time were recorded and represented in Figure 11. In Figure 11, the electrical power generated by the fuel cell and the control voltage applied to the pump driver are also represented. In this figure, one can see that the pressure control loop started approximately at $25 \mathrm{~s}$. To increase the pressure within the reactor rapidly (around $50 \mathrm{mbar} / \mathrm{s}$ ), the maximum voltage was applied to the pump initially. The reference pressure was obtained at time $t$ $=100 \mathrm{~s}$. The pump control voltage was then forced to zero by the control loop, and the hydrogen pressure remained stable without consumption. 
As shown in Figure 11, upon initiation, a strong purge was applied to the fuel cell (by the fuel cell management unit) at time $t=190 \mathrm{~s}$. The purge created a decrease in the pressure inside the reactor that was rapidly compensated by the pressure control loop. During fuel cell operation, the management unit generates periodic purges and short circuits (every $5 \mathrm{~s}$ alternatively). As shown in Figure 11, for the time interval [200-280], pressure control is not affected by these disturbances. A variable load is applied to the fuel cell for the time interval [280-650]. It is noticed that an increased load on the fuel cell implies a rise in the amount of hydrogen consumed, yet the pressure remained almost constant throughout. This demonstrates the efficiency of the hydrogen pressure control strategy. At times $380 \mathrm{~s}$ and $500 \mathrm{~s}$, when the load was reduced, there occurred a pressure overshoot. This behavior is a consequence of a rapid decrease in the hydrogen demand and can be explained by the excess of water in the reactor since it is not possible to withdraw the injected water.

At time $t=630 \mathrm{~s}$, the pump control voltage had its maximal value, but the temperature in the reactor was decreasing. It means that all the powder is consumed. The pump control voltage was then forced two more times at $730 \mathrm{~s}$ and $780 \mathrm{~s}$ to check the progress of the reaction, thus confirmed by the constant decrease in pressure. In Figure 12, the electrical power signal is noisy. This is the result of the periodic short circuits and purges imposed on the fuel cell by its management unit.

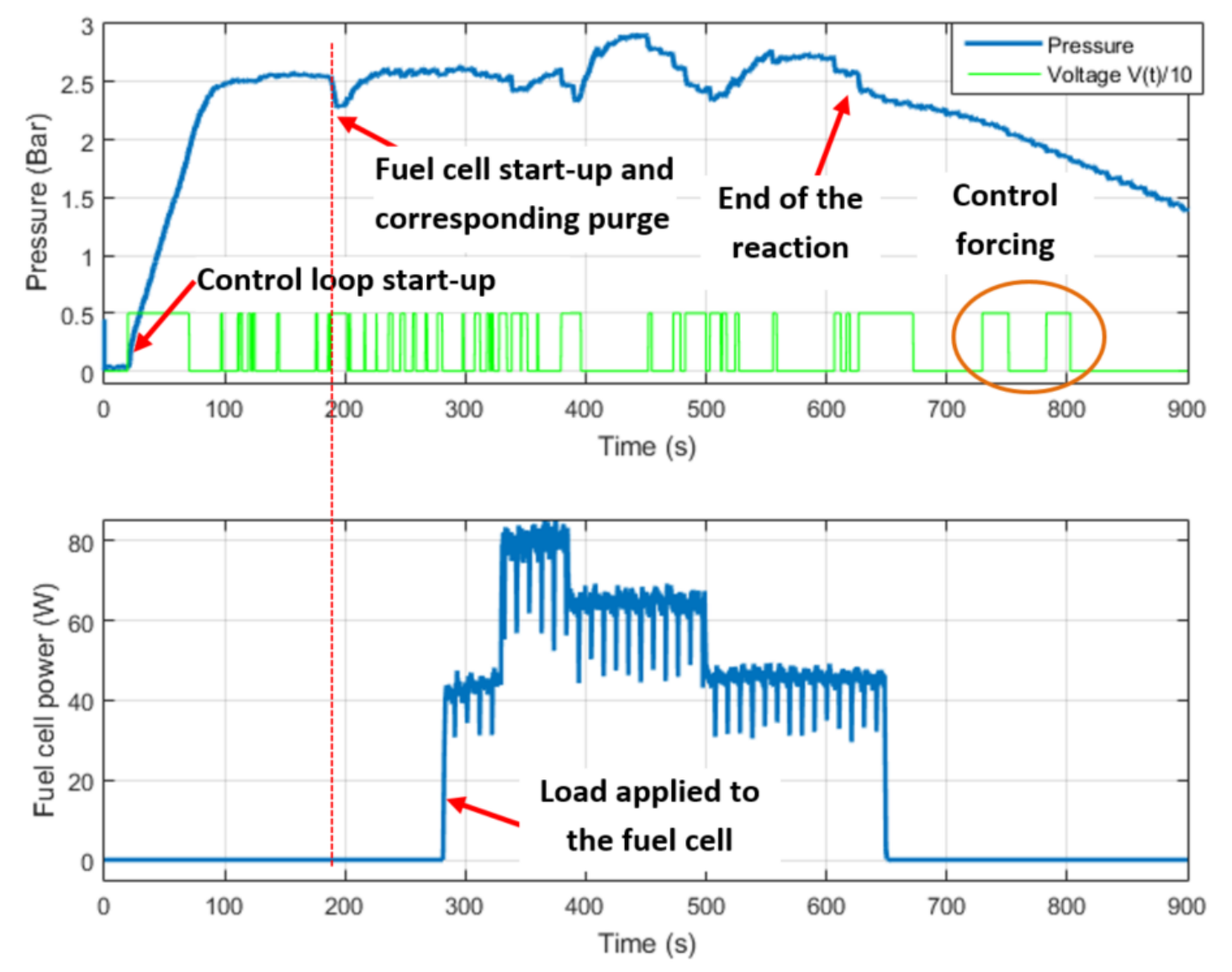

Figure 11 Closed-loop control of the reactor: control voltage applied to the pump (upgreen) and resulting pressure variation inside the reactor (up - blue), electrical power produced by the fuel cell (down). 

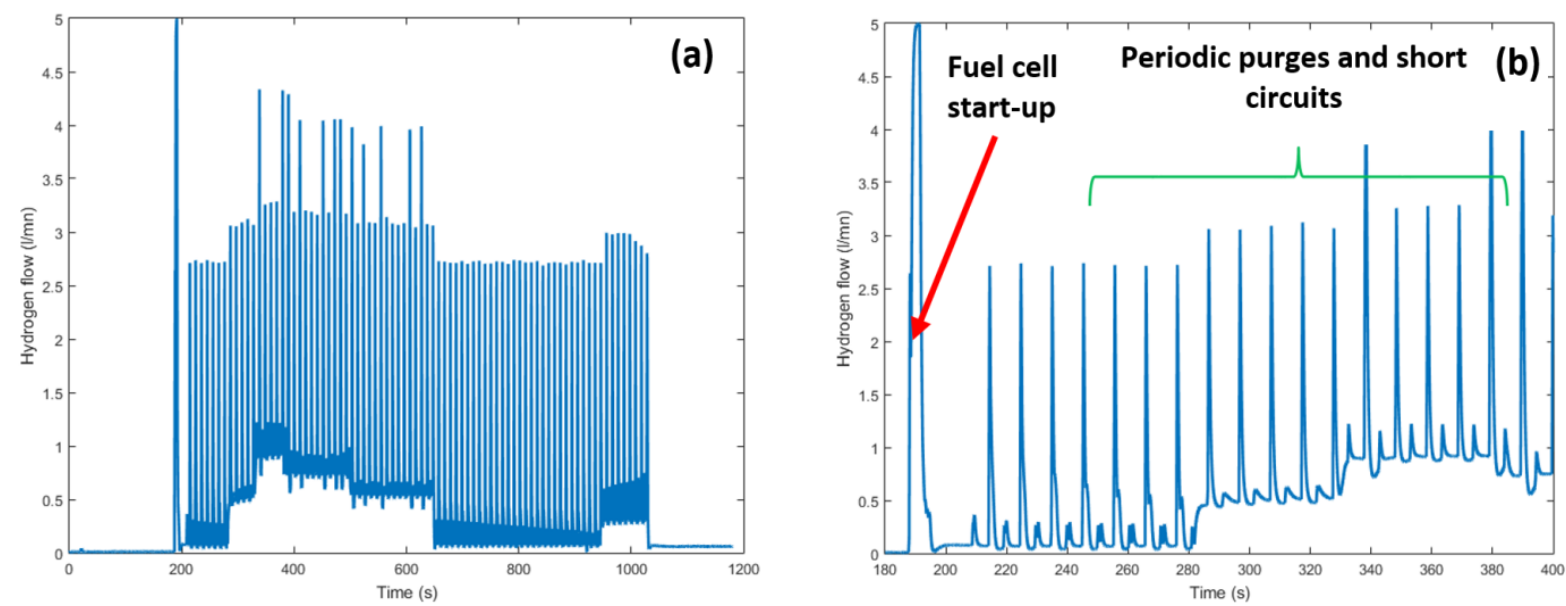

Figure 12 Closed-loop control of the reactor: hydrogen flow produced by the reactor during the test (a) and zoomed on the first $400 \mathrm{~s}(\mathrm{~b})$.

Several other tests were done on the testing bench, leading to promising results. It was thus decided to mount the reactor and its control system on an electric bike prototype. This bike was presented at the Intelligent Transport System (ITS) World Congress, designed by a team of the Bordeaux Institute of Technology. The bike provides electric power assistance proportional to the mechanical power exerted by the cyclist. To this end, special pedals that permit the measurement of pedaling effort were designed. On this bike prototype, shown in Figure 13, the electric power is produced by a $100 \mathrm{~W}$ fuel cell.

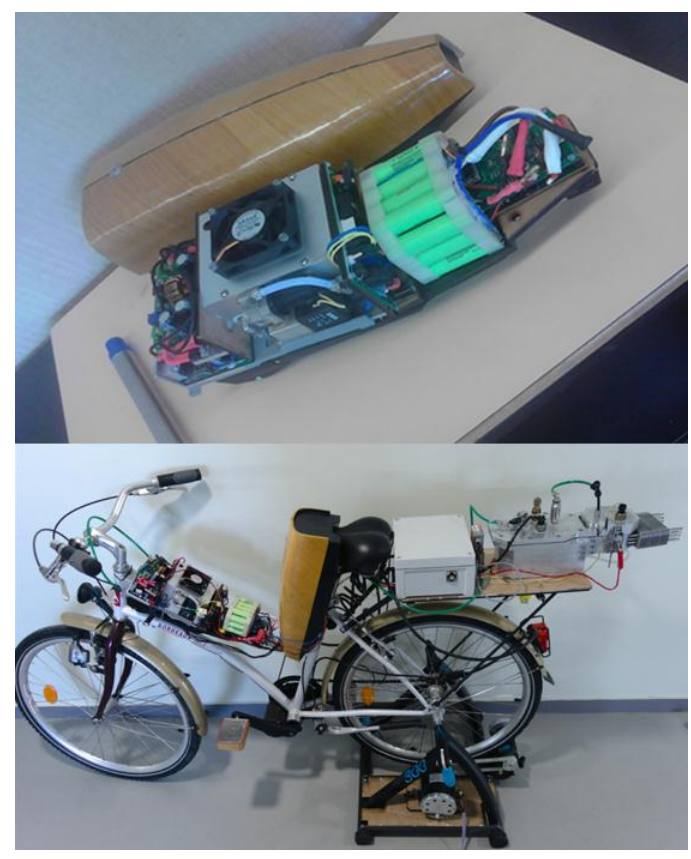

Figure 13 Fuel cell and control kit (up) installed on the bike prototype (down).

\section{Conclusion}

In this work, a solution to produce hydrogen on demand upon water hydrolysis using magnesium powder was presented. It involves a reactor whose internal pressure is adjusted by 
controlling the hydrolysis reaction. The control is achieved using an instrumental reactor that maintains a constant hydrogen pressure inside a buffer tank, located upstream of the fuel cell. This system permits a satisfactory supply to the fuel cell despite the large and abrupt variations in the electric load. A very efficient and environmentally safe powdered mixture was found (Mg-10 wt.\% G) to be used as a combustible. The hydrolysis reaction associated with the designed reactor thus solves the twofold problem of production and storage encountered in green mobility applications. The reasons that could limit the deployment of the solution presented in the paper are the cost of the material used for hydrolysis (Mg), and the heat produced during the reaction. Regarding the cost, the authors are currently seeking to use scraps of magnesium alloy and other compounds. Regarding the heat produced, the authors are looking for solutions to improve dissipation or use it for energy requirements.

\section{Acknowledgments}

The authors acknowledge the AST society, the Aquitaine SATT, for the funding of the prototype presented in this paper in the form of the HELP maturation project.

\section{Author Contributions}

Manuel Legree and Abdel salam Awad contributed to the optimisation of the magnesium mixture used to produce hydrogen.

Jocelyn Sabatier contributed to the hydrolysis reaction kinetic modelling and to the control of the reactor for a hydrogen on demand production, to the design of the reactor and of the electric bike prototypes.

Fabrice Mauvy contributed to the optimisation of the magnesium mixture used to produce hydrogen and to the design of the reactor and of the electric bike prototypes.

Jean-Louis Bobet contributed to the optimisation of the magnesium mixture used to produce hydrogen and to the design of the reactor prototype.

Matthieu Faessel and Frédéric Bos contributed to the design and manufacture of the reactor and electric bike prototypes.

\section{Competing Interests}

The authors have declared that no competing interests exist.

\section{References}

1. Naik KM, Sampath NS. Cubic $\mathrm{Mo}_{6} \mathrm{~S}_{8}$, efficient electrocatalyst towards hydrogen evolution over wide $\mathrm{pH}$ range. Electrochim Acta. 2017; 252: 408-415.

2. Naik KM, Higuchi $\mathrm{E}$, Inoue $\mathrm{H}$. Two-dimensional oxygen-deficient $\mathrm{TiO}_{2}$ nanosheets-supported Pt nanoparticles as durable catalyst for oxygen reduction reaction in proton exchange membrane fuel cells. J Power Sources. 2020; 455: 227972.

3. Li C, Peng P, Zhou DW, Wan L. Research progress in LiBH4 for hydrogen storage: A review. Int J Hydrogen Energ. 2011; 36: 14512-14526.

4. Aiello R, Matthews MA, Reger DL, Collins JE. Production of hydrogen gas from novel chemical hydrides. Int J Hydrogen Energ. 1998; 23: 1103-1108. 
5. Weng B, Wu Z, Li Z, Yang H, Leng HY. Enhanced hydrogen generation by hydrolysis of LiBH4 doped with multiwalled carbon nanotubes for micro proton exchange membrane fuel cell application. J Power Sources. 2011; 196: 5095-5101.

6. Kojima Y, Suzuki KI, Kawai Y. Hydrogen generation from lithium borohydride solution over nano-sized platinum dispersed on LiCoO2. J Power Sources. 2006; 155: 325-328.

7. Murugesan S, Subramanian V. Effect of acid accelerators on hydrogen from solid sodium borohydride using small scale devices. J Power Sources. 2009; 187: 216-223.

8. Dai HB, Liang Y, Wang P, Cheng HM. Amorphous cobalt boron/nickel faom as an effective catalyst for hydrogen generation from alkaline sodium borohydride solution. J Power Sources. 2008; 177: 17-23.

9. Baydaroglu F, Ozdemir E, Hasimoglu A. An effective synthesis route for improving the catalytic activity of carbon-supported Co-B catalyst for hydrogen generation through hydrolysis of $\mathrm{NaBH}_{4}$. Int J Hydrogen Energ. 2014; 39: 1516-1522.

10. Ocon JD, Tuan TN, Yi Y, de Leon RL, Lee JK, Lee J. Ultrafast and stable hydrogen generation from sodium borohydride in methanol and water over Fe-B nanoparticles. J power sources. 2013; 243: 444-450.

11. Wang $\mathrm{HZ}$, Leung DYC, Leung $\mathrm{MKH}, \mathrm{Ni}$ M. A review on hydrogen production using aluminum and aluminum alloys. Renew Sustain Energ Rev. 2009 ; 13: 845-853.

12. Fan MQ, Sun LX, Xu F. Feasibility study of hydrogen production for micro fuel cell from activated Al-In mixture in water. Energy. 2010; 35: 1333-1337.

13. Eom K, Cho EA, Kwon HS. Feasibility of on-board hydrogen production from hydrolysis of AlFe alloy for PEMFCs. Int J Hydrogen Energ. 20113; 36: 12338-12342.

14. Kim MJ, Eom KS, Kwon JY, Cho EA, Kwon HS. On-board hydrogen production by hydrolysis from designed $\mathrm{Al}-\mathrm{Cu}$ alloys and the application of this technology to polymer electrolyte membrane fuel cells. J Power Sources. 2012; 217: 345-350.

15. Al-Othman A, Zhu $\mathrm{Y}$, Tawalbeh M, Tremblay AY, Ternan M. Proton conductivity and morphology of new composite membranes based on zirconium phosphates, phosphotungstic acid, and silicic acid for direct hydrocarbon fuel cells applications. J Porous Mat. 2017; 24: 721-729.

16. Mohammed $\mathrm{H}$, Al-Othman A, Nancarrow $\mathrm{P}$, Elsayed $\mathrm{Y}$, Tawalbeh $\mathrm{M}$. Enhanced proton conduction in zirconium phosphate/ionic liquids materials for high-temperature fuel cells. Int J Hydrogen Energ. 2019. Available from: https://doi.org/10.1016/j.ijhydene.2019.09.118.

17. Muthuraja P, Prakash S, Shanmugam VM, Radhakrsihnan S, Manisankar P. Novel perovskite structured calcium titanate-PBI composite membranes for high-temperature PEM fuel cells: Synthesis and characterizations. Int J Hydrogen Energ. 2018; 43: 4763-4772.

18. Li J, Wang S, Liu F, Tian X, Wang X, Chen X, et al. HT-PEMs based on nitrogen-heterocycle decorated poly (arylene ether ketone) with enhanced proton conductivity and excellent stability. Int J Hydrogen Energ. 2018; 43: 16248-16257.

19. Teixeira FC, de Sá Al, Teixeira APS, Rangel CM. Enhanced proton conductivity of Nafionazolebisphosphonate membranes for PEM fuel cells. New J Chem. 2019; 43: 15249.

20. David E. An overview of advanced materials for hydrogen storage. J Mater Process Tech. 2005; 162-163: 169-177.

21. Hiraki T, Hiroi S, Akashi T, Okinaka N, Akiyama T. Chemical equilibrium analysis for hydrolysis of magnesium hydride to generate hydrogen. Int J Hydrogen Energ. 2012; 37: 12114-12119. 
22. Liu Y, Wang X, Liu H, Dong Z, Cao G, Yan M. Exploration of hydrogen generation from an Mg$\mathrm{LiBH}_{4}$ system improved by $\mathrm{NiCl}_{2}$ addition. J Power Sources. 2014; 251: 459-465.

23. Pourbaix M, Burbank J. Atlas D-equilibres electrochimiques. J Electrochem Soc. 1964; 111 : $14 C$.

24. Grosjean $\mathrm{MH}$, Zidoune $\mathrm{M}$, Roué $\mathrm{L}$, Huot J, Schulz R. Effect of ball milling on the corrosion resistance of magnesium in aqueous media. Electrochim Acta. 2004; 49: 2461-2470.

25. Tayeh T, Awad AS, Nakhl M, Zakhour M, Silvain JF, Bobet JL. Production of hydrogen from magnesium hydrides hydrolysis. Int J Hydrogen Energ. 2014; 39: 3109-3117.

26. Grosjean $\mathrm{MH}$, Zidoune $\mathrm{M}$, Roué L. Hydrogen production from highly corroding Mg- based materials elaborated by ball milling. J Alloy Compd. 2005; 404-406: 712-715.

27. Huot J, Liang G, Schulz R. Magnesium-based nanocomposites chemical hydrides. J Alloy Compd. 2003; 353: L12-L15.

28. Tessier JP, Palau P, Huot J, Schulz R, Guay D. Hydrogen production and crystal structure of ball-milled $\mathrm{MgH}_{2}-\mathrm{Ca}$ and $\mathrm{MgH}_{2}-\mathrm{CaH}_{2}$ mixtures. J Alloy Compd. 2004; 376: 180-185.

29. Liu Y, Wang X, Dong Z, Liu H, Li S, Ge H, et al. Hydrogen generation from the hydrolysis of $\mathrm{Mg}$ powder ball-milled with $\mathrm{AlCl}_{3}$. Energy. 2013; 53: 147-152.

30. Yu SH, Uan JY, Hsu TL. Effects of concentrations of $\mathrm{NaCl}$ and organic acid on generation of hydrogen from magnesium metal scrap. Int J Hydrogen Energ. 2012; 37: 3033-3040.

31. Wang S, Sun LX, Xu F, Jiao CL, Zhang J, Zhou HY, et al. Hydrolysis reaction of ball-milled Mgmetal chlorides composite for hydrogen generation for fuel cells. Int J Hydrogen Energ. 2012; 37: 6771-6775.

32. Zou MS, Yang RJ, Guo XY, Huang HT, He JY, Zhang P. The preparation of Mg-based hydroreactive materials and their reactive properties in seawater. Int J Hydrogen Energ. 2011; 36: 6478-6483.

33. Kravchenko OV, Sevastyanova LG, Urvanov SA, Bulychev BM. Formation of hydrogen from oxidation of $\mathrm{Mg}, \mathrm{Mg}$ alloys and mixture with $\mathrm{Ni}, \mathrm{Co}, \mathrm{Cu}$ and $\mathrm{Fe}$ in aqueous salt solutions. Int J Hydrogen Energ. 2014; 39: 5522-5527.

34. Kravchenko OV, Sevastyanova LG, Genchel VK, Bulychev BM. Hydrogen generation from magnesium oxidation by water in presence of halides of transition and non-transition metals. Int J Hydrogen Energ. 2015; 40: 12072-12077.

35. Hong SH, Kim HJ, Song MY. Rate enhancement of hydrogen generation through the reaction of magnesium hydride with water by $\mathrm{MgO}$ addition and ball milling. J Ind Eng Chem. 2012; 18: 405-408.

36. Kushch SD, Kuyunko NS, Nazarov RS, Tarasov BP. Hydrogen-generating compositions based on magnesium. Int J Hydrogen Energ. 2011; 36: 1321-1325.

37. Makar GL, Kruger J. Corrosion studies of rapidly solidified magnesium alloys. J Electrochem Soc. 1990; 137: 414-421.

38. Song G, Atrens A. Corrosion mechanisms of magnesium alloys. Adv Eng Mater. 1990; 1: 1133.

39. Figen $\mathrm{AK}$, Coşkuner $\mathrm{B}, \mathrm{Pişkin} \mathrm{S}$. Hydrogen generation from waste $\mathrm{Mg}$ based material in various saline solutions $\left(\mathrm{NiCl}_{2}, \mathrm{CoCl}_{2}, \mathrm{CuCl}_{2}, \mathrm{FeCl}_{2}, \mathrm{MnCl}_{2}\right)$. Int J Hydrogen Energ. 2015; 40: 7483-7489.

40. Figen AK, Filiz BC. Hydrogen production by the hydrolysis of milled waste magnesium scraps in nickel chloride solutions and nickel chloride added in Marmara Sea and Aegean Sea Water. Int J Hydrogen Energ. 2015; 40: 16169-16177. 
41. Uan JY, Cho CY, Liu KT. Generation of hydrogen from magnesium alloy scraps catalyzed by platinum-coated titanium net in $\mathrm{NaCl}$ aqueous solution. Int J Hydrogen Energ. 2007; 32: 2337-2343.

42. Cho CY, Wang KW, Uan JY. Evaluation of a new hydrogen generating system: Ni- rich magnesium alloy catalyzed by platinum wire in sodium chloride solution. Mater Trans. 2005; 46: 2074-2078.

43. Uan JY, Lin MC, Cho CY, Liu KT, Lin HI. Producing hydrogen in an aqueous $\mathrm{NaCl}$ solution by the hydrolysis of metallic couples of low-grade magnesium scrap and noble metal net. Int J Hydrogen Energ. 2009; 34: 1677-1687.

44. Öz Ç, Coşkuner Filiz B, Kantürk Figen A. The effect of vinegar-acetic acid solution on the hydrogen generation performance of mechanochemically modified Magnesium (Mg) granules. Energy. 2017; 127: 328-334.

45. Uan JY, Yu SH, Lin MC, Chen LF, Lin HI. Evolution of hydrogen from magnesium alloy scraps in citric acid-added seawater without catalyst. Int J Hydrogen Energ. 2009; 34: 6137-6142.

46. Yu SH, Uan JY, Hsu TL. Effects of concentrations of $\mathrm{NaCl}$ and organic acid on generation of hydrogen from magnesium metal scrap. Int J Hydrogen Energ. 2012; 37: 3033-3040.

47. Huang M, Ouyang L, Chen Z, Peng C, Zhu X, Zhu M. Hydrogen production via hydrolysis of Mgoxide composites. Int J Hydrogen Energ. 2017; 42: 22305-22311.

48. Alasmar E, Awad AS, Hachem D, Tayeh T, Nakhl M, Zakhour M, et al. Hydrogen generation from Nd-Ni-Mg system by hydrolysis reaction. J Alloy Compd. 2018; 740: 52-60.

49. Awad AS, El-Asmar E, Tayeh T, Mauvy F, Nakhl M, Zakhour M, et al. Effect of carbons ( $G$ and $\mathrm{CFs}), \mathrm{TM}\left(\mathrm{Ni}, \mathrm{Fe}\right.$ and $\mathrm{Al}$ ) and oxides $\left(\mathrm{Nb}_{2} \mathrm{O}_{5}\right.$ and $\left.\mathrm{V}_{2} \mathrm{O}_{5}\right)$ on hydrogen generation from ball milled Mg-based hydrolysis reaction for fuel cell. Energy. 2016; 95: 175-186.

50. Huang M, Ouyang L, Liu J, Wang H, Shao H, Zhu M. Enhanced hydrogen generation by hydrolysis of $\mathrm{Mg}$ doped with flower-like $\mathrm{MoS}_{2}$ for fuel cell applications. J Power Sources. 2017; 365: 273-281.

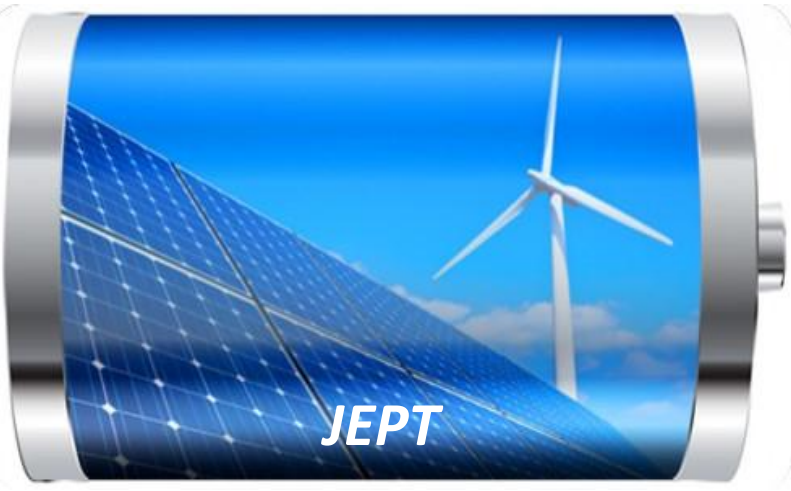

Enjoy JEPT by:

1. Submitting a manuscript

2. Joining in volunteer reviewer bank

3. Joining Editorial Board

4. Guest editing a special issue

For more details, please visit: http://www.lidsen.com/journal/jept 